\title{
Bioremediation Efficiency of Heavy Metals and Azo Dyes by Individual or Consortium Bacterial Species Either as Free or Immobilized Cells: A Comparative Study
}

\author{
Nanis G. Allam ${ }^{\#}$ \\ Botany Department, Microbiology Section, Faculty of Science, Tanta University, \\ Tanta, Egypt.
}

\begin{abstract}
$\mathbf{T}$ HE OBJECTIVE of the present study was to compare between free and immbolized bacterial cultuer/s in bioremediation of heavy metals and dyes to reduce environmental pollutants with the help of biological entities. The bacterial consortium consisting of Sphingomonas paucimobilis, Rhizobium radiobacter, and Bacillus subtilis was developed due to capabilities of the three bacterial species to remove heavy metals from industrial waste water and decolorize methyl orange and Congo red textile azo dyes than their corresponding single cultures. The immobilization of bacterial consortium on Ca-alginate increased its heavy metals removal efficiency more than $10 \%$ compared to consortium of free cells after 4 days. Also, decolorization ability of immobilized consortium was conducted for shorter time and higher concentrations of dyes than that of free one. The greater efficiency of immobilized consortium than free single culture may be correlated to synergistic activity of different metabolites of bacterial cultures and protection of cells from toxic pollutants that provided by $\mathrm{Ca}$-alginate matrices which promoting an efficient bio-treatment of industrial effluents containing dyes and heavy metals.
\end{abstract}

Keywords: Single culture, Immobilization, Heavy metals, Decolorization, Azo dyes, Consortium.

\section{Introduction}

Heavy metal pollution is one of the most important environmental problems nowadays, especially in relation to water contamination. Several industries, mining and smelting, as well as production of fuel, energy, fertilizers, metallurgy, electroplating, electrolysis, leather working and photography (Wang et al., 2009) produce waste and waste waters that are discharged in water courses threatening the ecosystems and ultimately human health.

Bioremediation processes are considered superior to physicochemical methods, such as ion exchange, electrochemical treatment, precipitation, and heat evaporation, because of their lower cost and greater efficiency in treating systems in which metal concentrations are low (Gadd \& White, 1993). Bacteria, molds, yeasts, and seaweed have been used to remove metals from wastewater (Ahluwalia \& Goyal, 2007).

Bacteria have a high surface area to volume ratio and can thus provide a large contact surface, which allows the interaction with metals in its surroundings and have been successfully used as biosorbents (Zouboulis et al., 2004 and Ziagova et al., 2007).

The use of native biomass (such as bacteria, yeast, fungi and algae) for degradation of toxic compounds in freely suspended state is limited owing to their inherent disadvantages such as small particle size, possible clogging and low mechanical strength of the biomass (Godjevargova et al., 2004).

Immobilization of whole cells for the degradation of different compounds in wastewater has several advantages to provide stability; (1) High activity, yield and good operational (2) Separating cell mass from bulk liquid for possible reuse (Reischwitz et al., 1995), when immobilized microbial cells are used, the efficacy of biodegradation is often improved. Calciumalginate (Ca-alginate) has been widely employed for immobilization of enzymes or whole cells since it is less toxic than synthetic polymers, easily gelled under mild conditions and inexpensive (Wang et al., 2007).

\#Corresponding author emails:nallam991@gmail.com, nanisallam@science.tanta.edu.eg DOI: $10.21608 /$ ejbo.2017.689.1040 
Although Bacillus biomass has been used for removal of heavy metal from aqueous solution, the researches on heavy metal removal by immobilized Bacillus biomass from the solutions were very limited (Xu et al., 2011).

The environmental problems associated with textile activities are caused mainly by the extensive use of dyes (Peralta-Zamora et al., 2003) and discharge resulted water without pretreatment. Azo dyes are mostly used in the textile industry due to their extensive variety of color shades and brilliant colors despite that they belonging to xenobiotic pollutants (Kunz et al., 2002 and Wang et al., 2009). Reduction of color from dye bearing wastewater is a complex problem because of difficulty in treating such waste waters by conventional treatment methods (Kumar et al., 2006).

The extensive discharge of textile dyes in industrial waste water effluent and the recalcitrant nature with carcinogenic or mutagenic properties of azo dyes give strong attention to exploring efficient and environmentally friendly approaches for waste water bio-remediation (Ali et al., 2014).

Decolorization of synthetic dyes using consortia offers advantages over the use of single microbial strains (Sudha et al., 2014) due to higher degrees of biodegradation resulted from synergistic metabolic activities of the microbial community (Khehra et al., 2003 and Ali, 2010).

The present study aimed to promote an effective bioremediation tool of industrial effluents which containing heavy metals and textile azo dyes by using free or immobilized bacterial consortium.

\section{Materials and Methods}

Sampling

In the present study the industrial wastewater samples were collected from industrial region of EL-Mahalla EL-Kobra El-Gharbia Governorate, Egypt which contained high concentrations of heavy metals and could be varied according to time of collection. The sampling was conducted for 2 months during 2016

\section{Investigated bacteria}

Sphingomonas paucimobilis, Rhizobium radiobacter, Bacillus subtilis and Bacillus pumilus were kindly provided from Microbiology Section, Botany Department, Faculty of Science, Tanta University. They were previously isolated and identified from sewage waste water.
Removal of heavy metals by free bacterial cells

The bacterial cells inoculum was prepared according to El-Gammal (2003) and the relative volume of inculum was $5 \%$ for pure or mixed cultures. All cultures were incubated in a shaker incubator $(120 \mathrm{rpm})$ at $37{ }^{\circ} \mathrm{C}$ for 2 or 4 days. At the end of incubation period, cells were separated by centrifugation $(5000 \mathrm{~g})$ and wastewater supernatant was taken for further analysis and compared with the control (without bacteria).

\section{Analytical methods}

The heavy metals $(\mathrm{Cd}, \mathrm{Cr}, \mathrm{Cu}, \mathrm{Zn}$, and $\mathrm{Pb})$ were measured in samples after digestion in concentrated $\mathrm{HNO}_{3}$ by ICP-OES model vista pro. All data represented means of three replica \pm Stander Deviation (SD).

\section{Azo dyes}

Methyl orange (with wave length $461 \mathrm{~nm}$; No. of azo bond Monoazo dye) and Congo red (with wave length $497 \mathrm{~nm}$; No. of azo bond; Dioazo dye) dyes were used during the present study. The decolorization of dyes was detected through measurement of absorbance at mentioned wave lengths by Shimadzu UV-3101 PC Spectrophotometer.

$$
\text { De-colorization }(\%)=[\mathbf{A}-\mathbf{B}] \times 100 / \mathbf{A}
$$

where, $\mathbf{A}=$ initial absorbance; $\mathbf{B}=$ final absorbance of decolorized medium.

\section{De-colorization of azo dyes}

Bacteria were cultured in nutrient broth medium under agitation (rotary shaker, $120 \mathrm{rpm}$ ) at $37 \pm 2{ }^{\circ} \mathrm{C}$ overnight and the cells were collected by centrifugation at $5,000 \mathrm{~g}$ for $5 \mathrm{~min}$. The cell pellets were washed twice with sterilized phosphate buffer and adjusted to an $\mathrm{OD}_{600}$ of 1.0. Each culture was tested individually for its decolorization effect. Cells of individual species were inoculated separately onto flasks at $1 \%$ $(\mathrm{v} / \mathrm{v})$. Samples were collected at different time points $(24 \mathrm{~h}, 36 \mathrm{~h}, 48 \mathrm{~h}, 60 \mathrm{~h}, 72 \mathrm{~h}, .$.$) to determine$ the dye decolarization rate.

\section{Development of bacterial consortium}

The selection of bacteria for the consortium development was based on their abilities to remove heavy metals and decolorize the dyes efficiently (about 60\%) and rapidly (within 3 days) according to Tony et al. (2009). Then, bacterial consortium was developed by mixing equal volumes of each 
isolate. For decolorization of dyes, the cells were inoculated into flasks at $4 \%(\mathrm{v} / \mathrm{v})$ level. All experiments were conducted in the same conditions consisting of a 500-ml flask containing $250 \mathrm{ml}$ of nutrient broth medium ( $\mathrm{pH} 7.5$ ). Culture medium was supplemented with different concentrations (50, 100, $150,200,250,300,350,400 \mathrm{mg} / \mathrm{L})$ of dyes to be tested (Cheriaa \& Bakhrouf, 2009). Flasks were incubated at $37^{\circ} \mathrm{C}$, in a rotary shaker $(120 \mathrm{rpm})$.

\section{Preparation of immobilized bacterial cells}

Immobilized consortium of bacterial cells of different pure cultures was prepared in equal ratios. The immobilization was carried out by bacterial cells inclusion into the alginate matrix, according to the method of Williams \& Munnecke (1981). In this purpose, 12.1 - $14.4 \mathrm{~g}$ d.w. bacterial mixture was mixed with $100 \mathrm{~mL}$ of $5 \%$ aqueous solution of calcium alginate. The biocatalysts particles were obtained by dripping this suspension at constant pressure through a capillary into a solution of $0.2 \% \mathrm{CaCl}_{2}$. Capillaries with three different diameters have been used and the obtained particles of immobilized cells had the following diameters: $3.0,3.6$ and $4.2 \mathrm{~mm}$. In all cases, the volumetric fraction of the immobilized cells into the medium was 0.10 according to Popa \& Asach (2012).

\section{Scanning electron microscopy}

Scanning electron microscope (SEM) was used to examine immobilization of bacterial mixture on calcium alginate (Hawser \& Douglas, 1994). Briefly, microbial biofilms (1 cm) were fixed with $2.5 \%$ glutaraldehyde in phosphate buffer for $2 \mathrm{~h}$ at room temperature. All samples were dried to critical point by polaron critical point drier, gold coated and viewed under SEM (Model JEOL, JSM-5200 LV) in SEM Unit, Faculty of Medicine, Tanta University.

\section{Results}

Bioremediation of Heavy metals in Industrial waste water

The ability of different investigated bacteria to remove heavy metals from industrial waste water was investigated by cultivating Sphingomonas paucimobilis, Rhizobium radiobacter, Bacillus subtilis or Bacillus pumilus for 2 or 4 days at $37^{\circ} \mathrm{C}$. The results in Table 1 and Fig. 1 revealed that the removal efficiency differed according to the types of heavy metals and bacterial cultures. All investigated individual bacterial cultures exhibited ability to remove heavy metals. $S$. paucimobilis was able to remove $\mathrm{Cu}, \mathrm{Fe}, \mathrm{Pb}, \mathrm{Cd}$ and $\mathrm{Cr}$ from industrial wastewater by $60,63,54,57$ and $53 \%$ respectively. While, removal efficiency of $R$. radiobacter was 49, 51, 45, 40 and 50\%, respectively. B. subtilis was able to remove $\mathrm{Cu}$, $\mathrm{Fe}, \mathrm{Pb}, \mathrm{Cd}$ and $\mathrm{Cr}$ from industrial waste water by $51,36,41,34$ and $37 \%$, respectively. Results also revealed that the heavy metals bioremediation ability of $B$. pumilus was the lowest among investigated bacteria.

It was also noticed that with increasing incubation time, heavy metals removal efficiency was increased as illustrated in Table 2 and Fig. 2. The removal efficiency of $\mathrm{Cu}, \mathrm{Fe}, \mathrm{Pb}, \mathrm{Cd}$ and $\mathrm{Cr}$ from industrial wastewater was $65,68,61,70$ and $72 \%$ by $S$. paucimobilis, 54, 59, 58, 62 and $65 \%$ by $R$. radiobacter, 57, 62, 58, 69 and $70 \%$ by $B$. subtilis and $55,60,57,62$ and $65 \%$ by B. pumilus, respectively, after 4 days of incubation.

TABLE 1. The capabilities of investigated bacteria to remove heavy metals from industrial wastewater after 2 days of incubation.

\begin{tabular}{|c|c|c|c|c|c|}
\hline \multirow[b]{2}{*}{ Metal conc. } & \multirow[b]{2}{*}{$\begin{array}{l}\text { Initial conc. } \\
\text { ( } \mathrm{mg} / \mathrm{L})\end{array}$} & \multicolumn{4}{|c|}{ Final concentration $(\mathrm{mg} / \mathrm{L})$} \\
\hline & & $\begin{array}{c}\text { Sphingomonas } \\
\text { paucimobilis }\end{array}$ & $\begin{array}{l}\text { Rhizobium } \\
\text { radiobacter }\end{array}$ & Bacillus subtilis & $\begin{array}{l}\text { Bacillus } \\
\text { pumilus }\end{array}$ \\
\hline $\mathrm{Cu}$ & $0.127 \pm 0.002$ & $0.051 \pm 0.000$ & $0.065 \pm 0.000$ & $0.062 \pm 0.000$ & $0.077 \pm 0.000$ \\
\hline $\mathrm{Fe}$ & $3.285 \pm 0.005$ & $1.211 \pm 0.004$ & $1.615 \pm 0.002$ & $2.11 \pm 0.006$ & $2.00 \pm 0.002$ \\
\hline $\mathrm{Pb}$ & $0.253 \pm 0.003$ & $0.116 \pm 0.001$ & $0.139 \pm 0.003$ & $0.150 \pm 0.001$ & $0.167 \pm 0.001$ \\
\hline $\mathrm{Cd}$ & $0.296 \pm 0.002$ & $0.126 \pm 0.002$ & $0.177 \pm 0.001$ & $0.194 \pm 0.001$ & $0.204 \pm 0.001$ \\
\hline $\mathrm{Cr}$ & $0.117 \pm 0.001$ & $0.055 \pm 0.000$ & $0.058 \pm 0.000$ & $0.074 \pm 0.000$ & $0.078 \pm 0.000$ \\
\hline
\end{tabular}




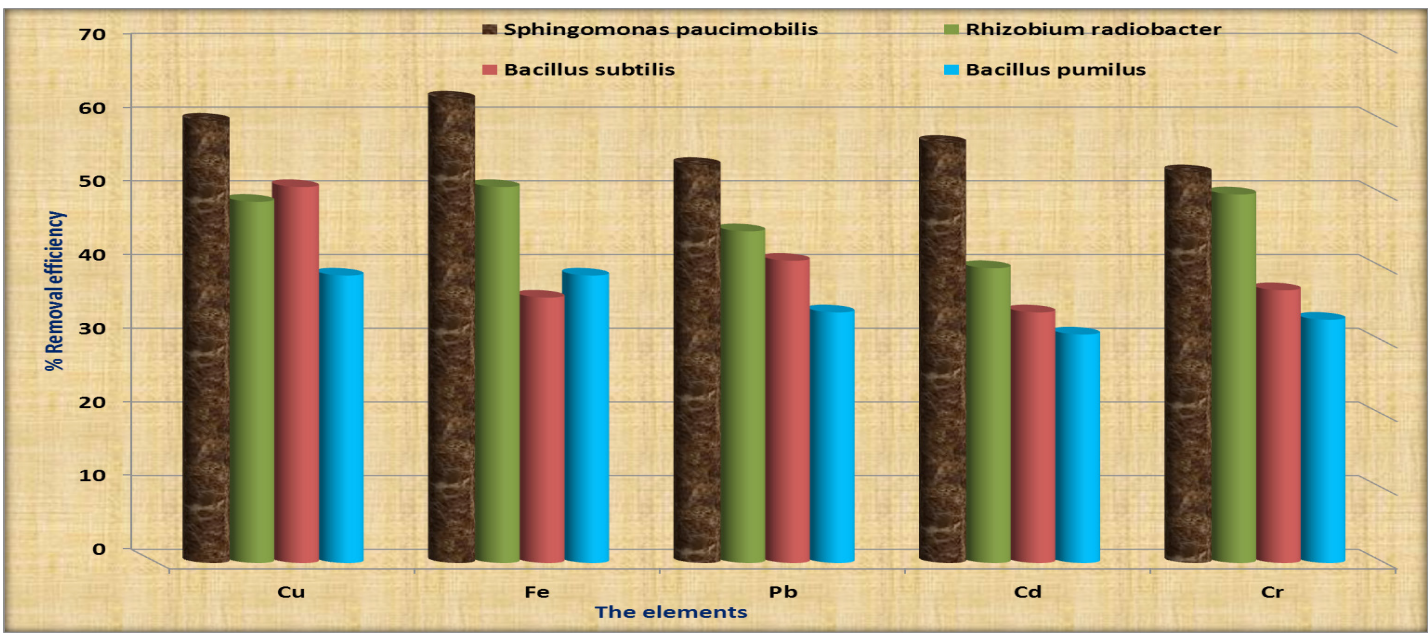

Fig. 1. The removal efficiency of heavy metals by individual bacterial species after 2 days of incubation.

TABLE 2. The capabilities of investigated bacteria to remove heavy metals from industrial wastewater after 4 days of incubation.

\begin{tabular}{lccccc}
\hline $\begin{array}{l}\text { Metal } \\
\text { conc. }\end{array}$ & $\begin{array}{c}\text { Initial conc. } \\
(\mathbf{m g} / \mathbf{L})\end{array}$ & $\begin{array}{c}\text { Sphingomonas } \\
\text { paucimobilis }\end{array}$ & $\begin{array}{c}\text { Final concentration }(\mathbf{m g} / \mathbf{L}) \\
\text { Radiobacter }\end{array}$ & $\begin{array}{c}\text { Bacillus } \\
\text { subtilis }\end{array}$ & $\begin{array}{c}\text { Bacillus } \\
\text { pumilus }\end{array}$ \\
\hline $\mathrm{Cu}$ & $0.325 \pm 0.002$ & $0.113 \pm 0.001$ & $0.149 \pm 0.001$ & $0.140 \pm 0.001$ & $0.147 \pm 0.001$ \\
$\mathrm{Fe}$ & $3.176 \pm 0.006$ & $1.012 \pm 0.004$ & $1.291 \pm 0.003$ & $1.201 \pm 0.004$ & $1.28 \pm 0.005$ \\
$\mathrm{~Pb}$ & $0.293 \pm 0.001$ & $0.114 \pm 0.001$ & $0.123 \pm 0.001$ & $0.122 \pm 0.001$ & $0.126 \pm 0.001$ \\
$\mathrm{Cd}$ & $0.327 \pm 0.002$ & $0.098 \pm 0.001$ & $0.123 \pm 0.001$ & $0.101 \pm 0.001$ & $0.125 \pm 0.000$ \\
$\mathrm{Cr}$ & $0.158 \pm 0.001$ & $0.044 \pm 0.000$ & $0.055 \pm 0.000$ & $0.047 \pm 0.000$ & $0.056 \pm 0.000$ \\
\hline
\end{tabular}

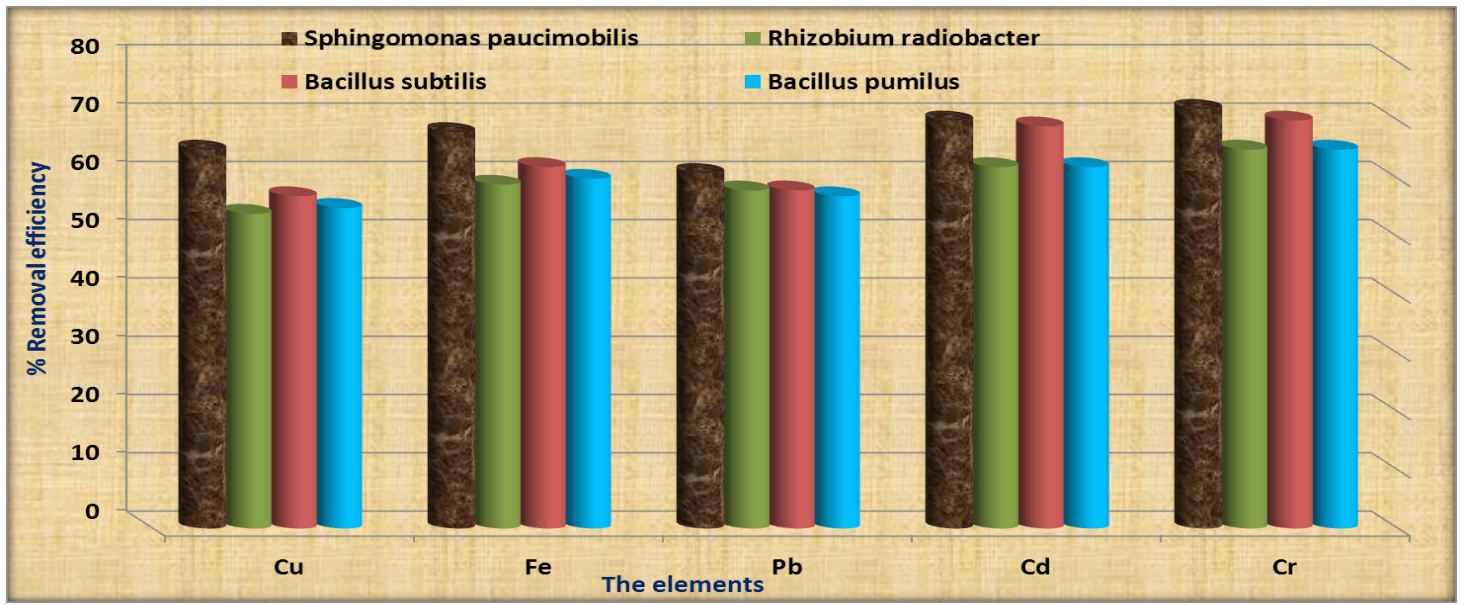

Fig. 2. The removal efficiency of heavy metals by individual bacterial species after 4 days of incubation

From the obtained results $S$. paucimobilis, $R$. radiobacter, and $B$. subtilis were chosen to be used in consortium to remove heavy metals.

Bioremediation of heavy metals by free or immobilized consortium of bacteria in industrial wastewater

The heavy metals removal efficiencies of free and immobilized bacterial consortium
(S.paucimobilis, R. radiobacter and B. subtilis) from wastewater after 2 and 4 days was shown in Tables 3 and 4 and Fig. 3 and 4. The results revealed that the removal efficiency of heavy metals either by free or immobilized bacterial consortium was better than single bacterial culture. 
TABLE 3. The capabilities of free and immobilized bacterial consortium to removal heavy metals from industrial wastewater after 2 days of incubation.

\begin{tabular}{lccc}
\hline Metal conc. & $\begin{array}{c}\text { Initial conc. } \\
(\mathbf{~ m g} / \mathbf{L})\end{array}$ & $\begin{array}{c}\text { Final concentration }(\mathbf{m g} / \mathbf{L}) \\
\text { consortium of Free } \\
\text { bacterial cells }\end{array}$ & $\begin{array}{c}\text { Immobilized bacterial } \\
\text { consortium }\end{array}$ \\
\hline $\mathrm{Cu}$ & $0.115 \pm 0.001$ & $0.036 \pm 0.000$ & $0.022 \pm 0.000$ \\
$\mathrm{Fe}$ & $3.327 \pm 0.007$ & $0.841 \pm 0.002$ & $0.430 \pm 0.002$ \\
$\mathrm{~Pb}$ & $0.241 \pm 0.001$ & $0.098 \pm 0.000$ & $0.073 \pm 0.001$ \\
$\mathrm{Cd}$ & $0.350 \pm 0.002$ & $0.117 \pm 0.001$ & $0.069 \pm 0.000$ \\
$\mathrm{Cr}$ & $0.121 \pm 0.0011$ & $0.051 \pm 0.000$ & $0.025 \pm 0.000$ \\
\hline
\end{tabular}

TABLE 4. The capabilities of free and immobilized bacterial consortium to removal heavy metals from industrial wastewater after 4 days of incubation.

\begin{tabular}{lccc}
\hline Metal conc. & $\begin{array}{c}\text { Initial conc. } \\
(\mathbf{~ m g} / \mathbf{L})\end{array}$ & $\begin{array}{c}\text { Final concentration }(\mathbf{m g} / \mathbf{L}) \\
\text { Consortium of free bacterial } \\
\text { cells }\end{array}$ & $\begin{array}{c}\text { Immobilized bacterial } \\
\text { consortium }\end{array}$ \\
\hline $\mathrm{Cu}$ & $0.64 \pm 0.002$ & $0.15 \pm 0.001$ & $0.03 \pm 0.000$ \\
$\mathrm{Fe}$ & $3.389 \pm 0.006$ & $0.675 \pm 0.002$ & $0.121 \pm 0.001$ \\
$\mathrm{~Pb}$ & $0.314 \pm 0.002$ & $0.076 \pm 0.000$ & $0.006 \pm 0.000$ \\
$\mathrm{Cd}$ & $0.285 \pm 0.001$ & $0.045 \pm 0.000$ & $0.013 \pm 0.000$ \\
$\mathrm{Cr}$ & $0.174 \pm 0.001$ & $0.038 \pm 0.000$ & $0.005 \pm 0.000$ \\
\hline
\end{tabular}

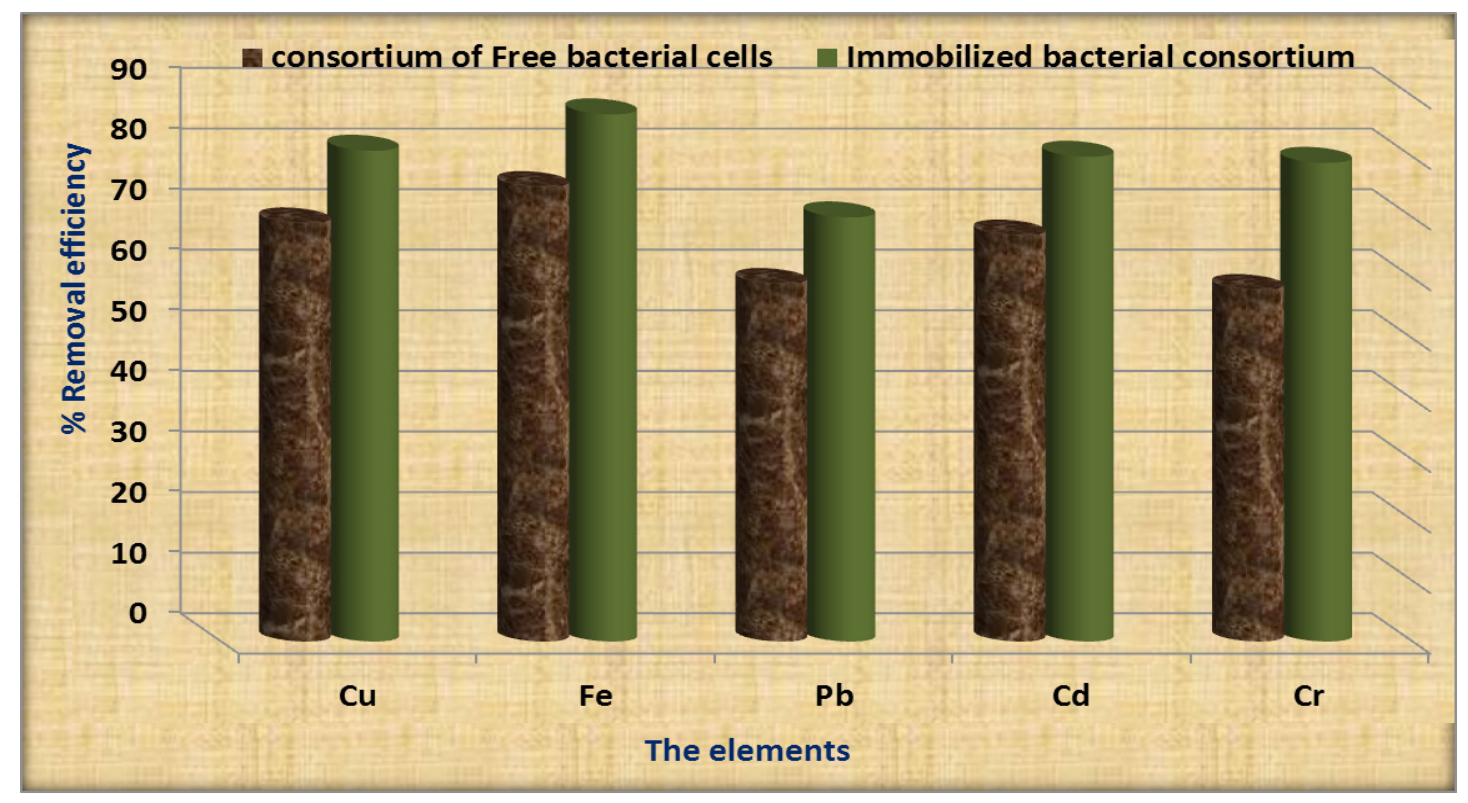

Fig. 3. The removal efficiency of heavy metals by free and immobilized bacterial consortium after 2 days of incubation. 


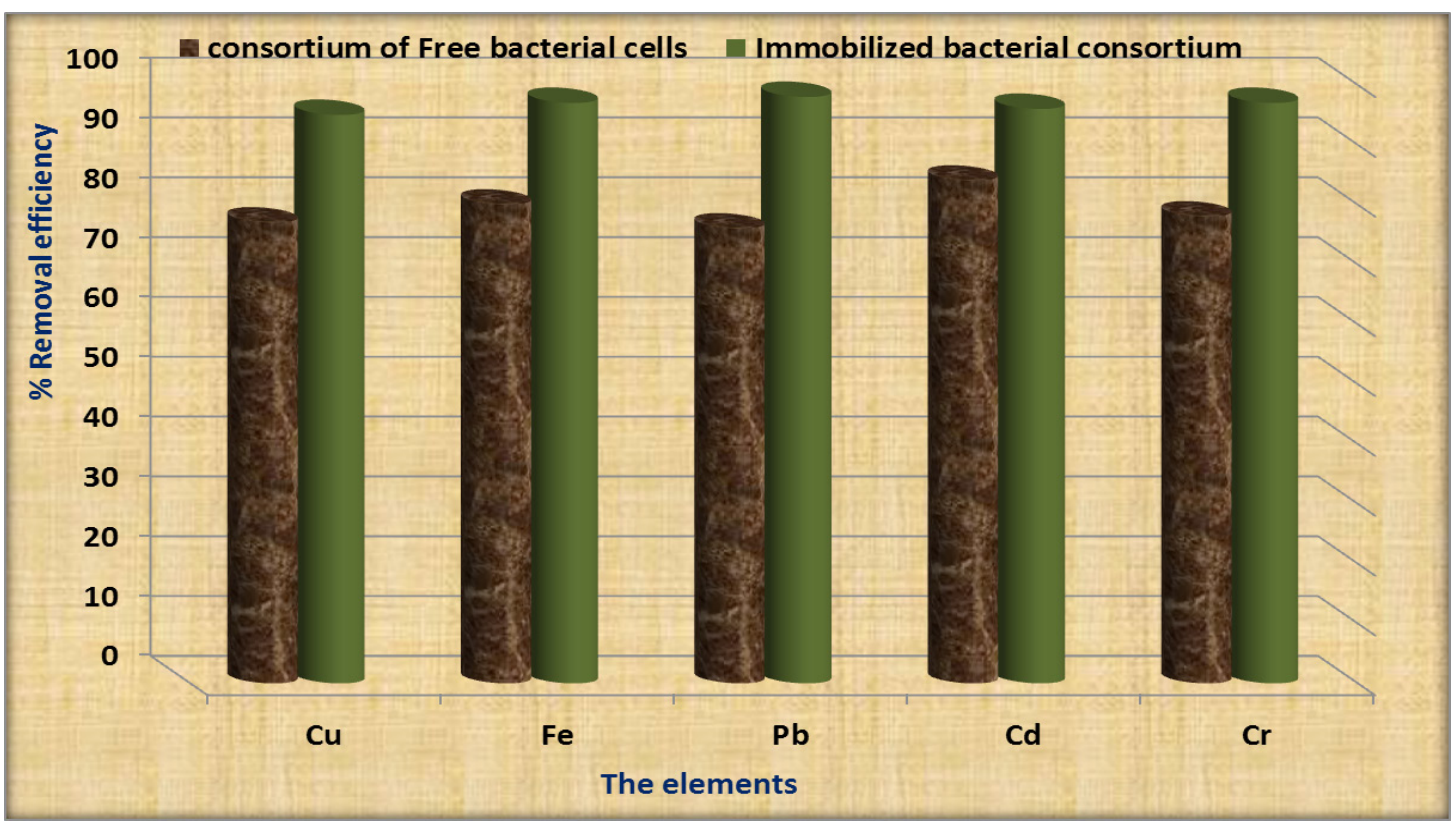

Fig. 4. The removal efficiency of heavy metals by free and immobilized bacterial consortium after 4 days of incubation.

The immobilized bacterial consortium gave higher removal efficiency of heavy metals after 4 days of incubation $(95,97,98,96$ and 97\% for $\mathrm{Cu}, \mathrm{Fe}, \mathrm{Pb}, \mathrm{Cd}$ and $\mathrm{Cr}$, respectively) than free consortium.

Bioremediation of azo dyes by single bacterial culture

In the case of two investigated azo dyes (methyl orange and Congo red), the test was conducted for 10 days. $S$. paucimobilis, $R$. radiobacter or $B$. subtilus started to degrade the dye at $50 \mathrm{mg} / \mathrm{L}$ after 2 days. While, B. pumilus failed to decolorize the 2 investigated dyes.
With increasing the concentrations of the dyes $(100,200,300,400-600 \mathrm{mg} / \mathrm{L})$ the ability of the bacteria to degrade the dye was decreased and required more days $(3,4,5-10$ day).

The three selected species of bacteria were able to decolorize dyes as illustrated in Table 5. Bacteria started to degrade the dye at $50 \mathrm{mg} / \mathrm{L}$ after 2 days with $89-73 \%$ and at $100 \mathrm{mg} / \mathrm{L}$ after 4 days with $84-71 \%$ decolorization rate. With increasing the concentrations of the dyes, the decolorization was conducted for more days and the decolorization rate was decreased.

TABLE 5. Decolorization (\%) of dyes by single bacterial culture after 2 and 4 days of incubation.

\begin{tabular}{|c|c|c|c|c|c|}
\hline \multirow{2}{*}{ Dyes } & \multirow{2}{*}{$\begin{array}{c}\text { Dye } \\
\text { Concentration } \\
(\mathrm{mg} / \mathrm{L})\end{array}$} & \multirow{2}{*}{ Days } & \multicolumn{3}{|c|}{ Bacteria isolates } \\
\hline & & & S. paucimobilis & R.radiobacter & B. subtilus \\
\hline \multirow{2}{*}{$\begin{array}{l}\text { Methyl } \\
\text { orange }\end{array}$} & 50 & 2 & $89 \%$ & $78 \%$ & $75 \%$ \\
\hline & 100 & 4 & $84 \%$ & $73 \%$ & $71 \%$ \\
\hline \multirow{2}{*}{$\begin{array}{l}\text { Congo } \\
\text { red }\end{array}$} & 50 & 2 & $76 \%$ & $63 \%$ & $54 \%$ \\
\hline & 100 & 4 & $69 \%$ & $58 \%$ & $50 \%$ \\
\hline
\end{tabular}


Bioremediation of azo dyes by free or immobilized bacterial consortium

Bacterial consortium was based on the three bacterial species ( $S$. paucimobilis, $R$. radiobacter and B. subtilus) was developed by mixing equal volumes of each individual one.

Bacterial consortium started to decolorize the dyes at $100 \mathrm{mg} / \mathrm{L}$ after $36 \mathrm{~h}$ with $91 \%$ decolorization rate for methyl orange and $88 \%$ for Congo red. While, the immobilized consortium began to decolorize the dyes after $24 \mathrm{~h}$ at $100 \mathrm{mg} / \mathrm{L}$ at $37^{\circ} \mathrm{C}$ and $\mathrm{pH} 7.0$ with $95 \%$ decolorization rate, for methyl orange and $90 \%$ for Congo red. The decolorization ability was conducted for several days and decolorizes the dyes till $600 \mathrm{mg} / \mathrm{L}$ after 4 days with $90 \%$ for methyl orange and $84 \%$ for Congo red.

\section{Scanning Electron Microscopy}

The scanning electronic micrographs of bacterial consortium as shown in Fig. 5 revealed that bacterial cells were successively impeded on $\mathrm{Ca}$ - alginate matrix and become immobilized.
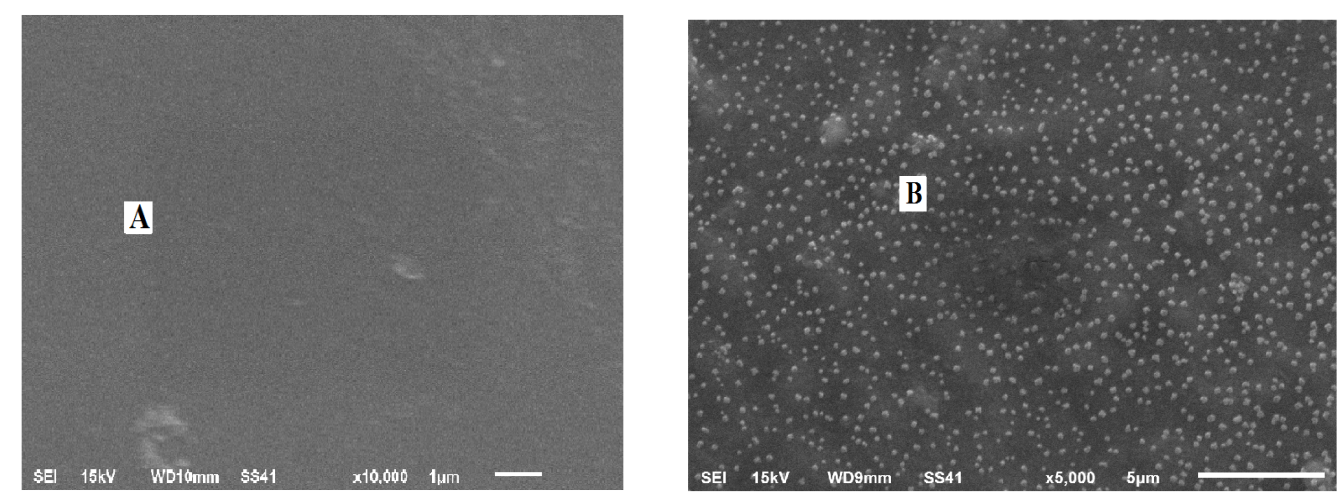

Fig. 5. Scanning electron microscope of immobilized Ca- alginate blank (A) and, Rhizobium radiobacter and Sphingomonas paucimobilis cells immobilized on Ca- alginate (B) at magnifiers power (10.000X) and $(5.000 \mathrm{X})$ respectively.

\section{Discussion}

The results in the present study indicated that immobilized bacterial consritum of the three bacterial species $(S$. paucimobilis, $R$. radiobacter and $B$. subtilis) had the ability to remove heavy metal ions from industrial waste water and decolorize two azo dyes more efficient than free bacterial cells of single culture or consortium. This could be attributed to matrices nature $(\mathrm{Ca}-$ alginate) which acts as cell protector against toxic pollutants in waste water by reducing the number of attack sites and by decreasing the flow rate toward the entrapped cells so the bioremediation capacity using immobilized consortium was stable than using free one. Also, synergistic metabolic activities of the different microbial communities in consortium enhanced bioremediation capacity than individual cultures as adopted by Khehra et al. (2005) and Ali (2010).

In the same context, Cui et al. (2013) used immobilized microorganisms to remove $\mathrm{Pb}(\mathrm{II})$ and COD efficiently by $92.0 \%$ and $85.0 \%$, respectively. Also, Akhtar et al. (2004) used Loofa sponge biomass in order to immobilize cells of Chlorella sorokiniana, to remove nickel (II) from aqueous solutions efficiently and the immobilized system accumulate $25 \%$ of nickel more than free cells after $20 \mathrm{~min}$ exposition. While, Safonova et al. (2004) found that the amounts of pollutants were significantly removed using a mixedimmobilization of selected consortium of several microalgal species (Chlorella sp., Scenedesmus obliquus, Stichococcus sp.) and several bacteria (Rhodococcus sp., Kibdelosporangium aridum) inside a highly contaminated pond and the removal efficiencies was $62 \%$ copper, $62 \%$ nickel, $90 \%$ zinc, 70\% manganese, and $64 \%$ iron.

There were several reports on the use of immobilized technique in the removal of various toxicants including heavy metals from polluted waste water (de-Bashan \& Bashan, 2010 and Gao et al., 2011).

In the present study, decolorization potency of consortium was more efficient than individual 
bacterial cultures. In the same connection, Mahmood et al. (2015) found that, the consortium of 6 bacterial isolates was able to decolorize $84 \%$, $84 \%, 85 \%, 85 \%$, and $82 \%$ of $200 \mathrm{ppm}$ of red, green, black, yellow, and mixed dyes within $24 \mathrm{~h}$ while individual strain required $72 \mathrm{~h}$.

The efficacy of $R$. radiobacter, $S$. paucimobilis and $B$. subtilis in decolorization of azo dyes (Cheriaa et al., 2012 and Ali et al., 2014) and removal of heavy metals (Xie et al., 2010; Gayathramma et al., 2013 and Wang et al., 2013) have been previously reported.

In the present investigation, it was observed that the metals removal efficiency depended on the type of bacteria being used. This observation was in agreement with Hamdy (2000) who found that the different metals uptake depended upon the type of bio-sorbent, which had different accumulation affinities towards the tested elements.

Scanning electron microscope (SEM) was applied in this study to show the immobilization of investigated microbial cells on Ca-alginate matrix, the heavy aggregations of cells on Caalginate revealed their affinity to be immobilized on Ca-alginate and reduced the number of attack sites. These results agree with Piccirillo et al. (2013) who found that bacterial strains were successfully immobilized without any pretreatment of the hydroxyapatite (HAp) surface, even if some differences could be seen between bacterial strains.

\section{References}

Akhtar, N., Iqbal, J. and Iqbal, M. (2004) Enhancement of lead (II) biosorption by microalgal biomass immobilized onto loofa (Luffa cylindrica) sponge. Eng Life Sci. 4(2), 171-178.

Ahluwalia, S.S. and Goyal, D. (2007) Microbial and plant derived biomass for removal of heavy metals from wastewater. Bioresour. Technol. 98, 2243 -2257 .

Ali, L., Alhassani, H., Karuvantevida, N., Rauf, M.A. and Ashraf, S.S. (2014) Efficient aerobic degradation of various azo dyes by a Sphingomonas sp. isolated from petroleum sludge. J. Bioremed Biodeg. 5 (3), 1-10.

Ali, L. (2010) Biodegradation of synthetic dyes-a review. Water Air Soil Pollut. 213, 251-273.

Cheriaa, J., Khaireddine, M., Rouabhia, M. and
Bakhrouf, A. (2012) Removal of Triphenylmethane Dyes by Bacterial consortium. Sci.World. J. 2012, $1-9$.

Cheriaa, J. and Bakhrouf, A. (2009) Triphenylmethanes, malachite green and crystal violet dyes decolourisation by Sphingomonas paucimobilis. Annals of Microbiol. 59 (1-5), 57-61.

Cui, L., Meng, Q., Bi, H., Zhou, L. and Ye, Z. (2013) Simultaneous removal of $\mathrm{Pb}(\mathrm{II})$ and chemical oxygen demand from aqueous solution using immobilized microorganisms on polyurethane foam carrier. Korean. J. Chem. Eng. 30 (9), 17291734.

De-Bashan, L.E. and Bashan, Y. (2010) Immobilized microalgae for removing pollutants: review of practical aspects. Bioresour. Technol. 101, 1611-1627.

El-Gammal, E.W. (2003) Role of some bacteria and cyanobacteria in treatment of polluted water. M.Sc. Thesis, Faculty of Sci., Tanta Univ. Egypt.

Gadd, G.M. and White, C. (1993) Microbial treatment of metal pollution a working biotechnology? Trends Biotechnol. 11, 353-359.

Gao, Q.T., Wong, Y.S.N. and Tam, F.Y. (2011) Removal and biodegradation of nonylphenol by immobilized Chlorella vulgaris. Bioresour. Technol. 102, 10230-10238.

Gayathramma, K., Pavani, K.V., Singh, A.R. and Deepti, S. (2013) Role of Bacillus subtilis in bioremediation of heavy metals. I JBR. 6 (1), 6-11.

Godjevargova, T., Mihova, S. and Gabrovska, K. (2004) Fixed-bed biosorption of $\mathrm{Cu}$ by polyacrylonitrileimmobilized dead cells of Saccharomyces cerevisiae. World. J. Microbiol. Biotecnol. 20, 273-279.

Hamdy, A.A. (2000). Biosorption of heavy metals by marine algae. Curr. Microbiol. 41(4), 232-238.

Hawser, S.P. and Douglas, L.J. (1994) Biofilm formation by Candida species on the surface of catheter materials in vitro. Infect Immun. 62, 287-295.

Keharia, H. and Madamwar, D. (2003) Bioremediation concepts for treatment of dye containing wastewater. A review. Indian J. Exp. Biol. 41, 1068-1075.

Khehra, M.S., Saini, H.S., Sharma, D.K., Chadha, B.S and Chimni, S.S. (2005) Decolorization of various azo dyes by bacterial consortium. Dyes and Pigm. 67, 5-61.

Kumar, K.V., Ramamurthi, V. and Sivanesan, S. (2006) Biosorption of malachite green, a cationic dye onto 
Pithophora sp., a fresh water algae. Dyes and Pigm. $69(1-2), 102-107$.

Kunz, A., Mansilla, H. and Durán, N.A. (2002) Degradation and toxicity study of three textile reactive dyes by ozone. Environ. Technol. 23 (8), 911-918.

Mahmood, R., Sharif, F., Ali, S. and Umar Hayyat, M., (2015) Enhancing the decolorizing and degradation ability of bacterial consortium isolated from textile effluent affected area and its application on seed germination. Sci. World J. 62, 81-95.

Reischwitz, A., Reh, K.D. and Buchholz, K. (1995) Unconventional immobilization of dextransucrase with alginate. Enzyme and Microb. Technol. J. 17, 457.

Peralta-Zamora, P., Pereira, C.M., Tiburtius, E.R.L., Moraes, S.G., Rosa, M.A., Minussi, R.C. and Durán, N. (2003) Decolorization of reactive dyes by immobilized laccase. Appl. Catal. B: Environ. 42(2), 131-144.

Popa, G.T. and Asachi, G.h. (2012) Kinetic studies on biodegradation of lipids from olive oil mill wastewater with free and immobilized Bacillus sp. cells. Sci. Study \& Res-Chemistry \& Chemical Eng. Biotech. Food Industry, 13 (1), 49 - 62.

Piccirillo, C., Pereira, S.I.A., Marques, A.P.G.C., Pullar, R.C., Tobaldi, D.M., Pintado, M.E. and Castro, P.M.L. (2013) Bacteria immobilisation on hydroxyapatite surface for heavy metals removal. J. Environ. Manage. 121, 87-95.

Safonova, E., Kvitko, K., Iankevitch, M., Surgko, L., Afti, I. and Reisser, W. (2004) Biotreatment of industrial wastewater by selected algal-bacterial consortia. Eng. Life Sci. 4, 347-353.

Sudha, M., Saranya, A., Selvakumar, G. and Sivakumar, N. (2014) Microbial degradation of azo dyes: a review. Int. J. Curr. Microbiol. App. Sci. 3(2), 670-690.

Tony, B.D., Goyal, D. and Khanna, S. (2009) Decolorization of textile azo dyes by aerobic bacterial consortium. IntBiodeter-Biodegr. 63(4), 462-469.
Wang, C. and Chen (2009) Biosorbents for heavy metals removal and their future. Biotechnol. Adv. 27, 195-226.

Wang, H., Su, J.Q., Zheng, X.W., Tian, Y., Xiong, X.J. and Zheng, T.L. (2009) Bacterial decolorization and degradation of the reactive dye Reactive Red 180 by Citrobacter sp. CK3. Int-Biodeter-Biodegr. 63(4), 395-399.

Wang, L., Yang, J., Chen, Z., Liu, X. and Fang, M. A. (2013) Mabiosorption of $\mathrm{Pb}$ (Ii) and $\mathrm{Zn}$ (Ii) by extracellular polymeric substance (Eps) of Rhizobium radiobacter: Equilibrium, kinetics and reuse studies. Arch. Environ. Prot. 39 (2), 129 - 140.

Wang, Y., Tian, Y., Han, B., Zhao, H.B., Bi, J.N. and Cai, B.L. (2007) Biodegradation of phenol by free and immobilized Acinetobacter sp. strain PD12. J. of Environ. Sci. 19, 222-225.

Xie, X., Fu, J., Wang, H. and Liu, J. (2010) Heavy metal resistance by two bacteria strains isolated from a copper mine tailing in China. African J. Biotechnol. 9 (26), 4056- 4066.

Xu, J., Song, X.C., Zhang, Q., Pana, H., Liang, Y., Fan, X.W. and Li, Y.Z. (2011) Characterization of metal removal of immobilized Bacillus strain CR-7 biomass from aqueous solutions. J. Hazard-Mater. $187,450-458$.

Ziagova, M., Dimitriadis, G., Aslanidou, D., Papaioannou, X., Tzannetaki, EI. and Liakopoulou-Kyriakides, M. (2007) Comparative study of $\mathrm{Cd}(\mathrm{II})$ and $\mathrm{Cr}(\mathrm{VI})$ biosorption on Staphylococcus xylosus and Pseudomonas sp. in single and by nary mixtures. Biores. Technol. 98, 2859-2865.

Zouboulis, A.I., Loukidou, M.X. and Matis, K.A. (2004) Biosorption of toxic metals from aqueous solutions by bacteria strains isolated from metal polluted soils. Process Biochem. 39, 909-916.

Williams, D. and Munnecke, D.M. (1981) The production of ethanol by immobilized yeast cells. Biotechnol. Bioeng. 23 (8), 1813-1825.

(Received 26/2/2017;

accepted 12/9/2017) 


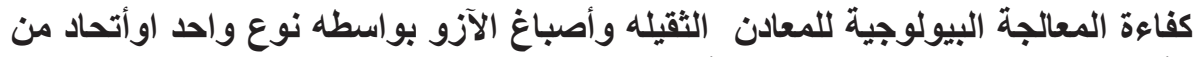 الأنواع البكتيريه إما فى صوره حره أو مثبته :دراسه مقارنها}

ناتيس جمال علام

قسم النبات ـ شعبه الميكروبيولوجى ـ كليه العلوم - جامعه طنطا ـ طنطا - مصر.

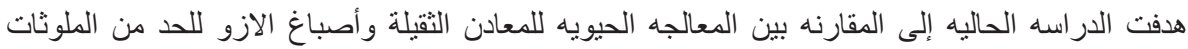

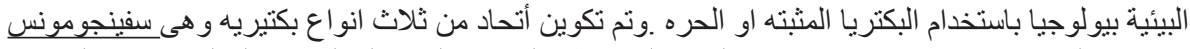

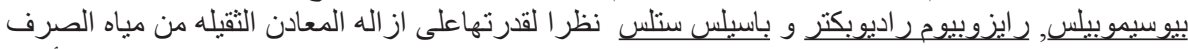

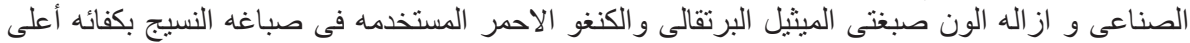

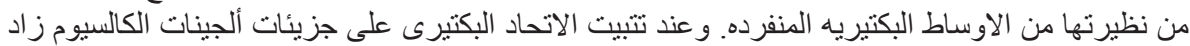

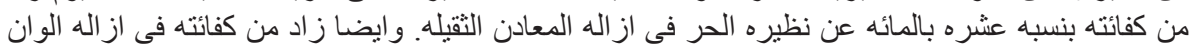

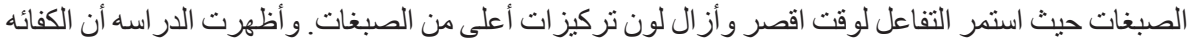

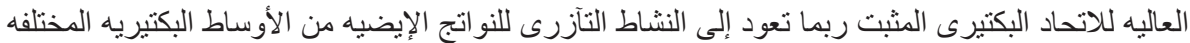

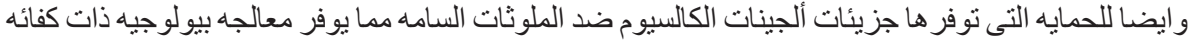

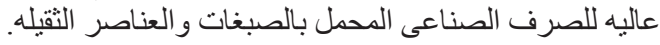

